\title{
Synergistic Enhancement of Thermal Conductivity and Dielectric Properties in $\mathrm{Al}_{2} \mathrm{O}_{3} / \mathrm{BaTiO}_{3} / \mathrm{PP}$ Composites
}

\author{
Junlong Yao ${ }^{1,2,3}{ }^{\text {, Li Hu }}{ }^{1}$, Min Zhou ${ }^{1}$, Feng You ${ }^{1}$, Xueliang Jiang ${ }^{1}$, Lin Gao ${ }^{2,4, *}$, Qing Wang ${ }^{2, *}$, \\ Zhengguang Sun ${ }^{3}$ and Jun Wang ${ }^{5}$ \\ 1 School of Materials Science and Engineering, Wuhan Institute of Technology, Wuhan 430205, China; \\ junlongyao@yahoo.com (J.Y.); hulidrifter@outlook.com (L.H.); hspike@sina.com (M.Z.); \\ youfeng.mse@wit.edu.cn (F.Y.); sjtujxl@163.com (X.J.) \\ 2 Department of Materials Science and Engineering, The Pennsylvania State University, \\ University Park, PA 16802, USA \\ 3 Ministry-of-Education Key Laboratory for the Green Preparation and Application of Functional Materials, \\ Hubei University, Wuhan 430062, China; sunshine@hubu.edu.cn \\ 4 School of Chemistry and Environmental Engineering, Jianghan University, Wuhan 430056, China \\ 5 State Key Laboratory of Environmental Aquatic Chemistry, Research Center for Eco-Environmental Sciences, \\ Chinese Academy of Sciences, Beijing 100085, China; junwang@rcees.ac.cn \\ * Correspondence: woshiyj12007@163.com (L.G.); wang@matse.psu.edu (Q.W.)
}

Received: 25 July 2018; Accepted: 21 August 2018; Published: 26 August 2018

check for updates

\begin{abstract}
Multifunctional polymer composites with both high dielectric constants and high thermal conductivity are urgently needed by high-temperature electronic devices and modern microelectromechanical systems. However, high heat-conduction capability or dielectric properties of polymer composites all depend on high-content loading of different functional thermal-conductive or high-dielectric ceramic fillers (every filler volume fraction $\geq 50 \%$, i.e., $f_{\text {filler }} \geq 50 \%$ ), and an overload of various fillers ( $f_{\text {thermal-conductive filler }}+f_{\text {high-dielectric filler }}>50 \%$ ) will decrease the processability and mechanical properties of the composite. Herein, series of alumina/barium titanate/polypropylene $\left(\mathrm{Al}_{2} \mathrm{O}_{3} / \mathrm{BT} / \mathrm{PP}\right)$ composites with high dielectric- and high thermal-conductivity properties are prepared with no more than $50 \%$ volume fraction of total ceramic fillers loading, i.e., $f_{\text {fillers }} \leq 50 \%$. Results showed the thermal conductivity of the $\mathrm{Al}_{2} \mathrm{O}_{3} / \mathrm{BT} / \mathrm{PP}$ composite is up to $0.90 \mathrm{~W} / \mathrm{m} \cdot \mathrm{K}$ with only $10 \%$ thermal-conductive $\mathrm{Al}_{2} \mathrm{O}_{3}$ filler, which is 4.5 times higher than the corresponding $\mathrm{Al}_{2} \mathrm{O}_{3} / \mathrm{PP}$ composites. Moreover, higher dielectric strength $\left(E_{\mathrm{b}}\right)$ is also found at the same loading, which is 1.6 times higher than $\mathrm{PP}$, and the $\mathrm{Al}_{2} \mathrm{O}_{3} / \mathrm{BT} / \mathrm{PP}$ composite also exhibited high dielectric constant $\left(\varepsilon_{\mathrm{r}}=18\right.$ at $\left.1000 \mathrm{~Hz}\right)$ and low dielectric loss $(\tan \delta \leq 0.030)$. These excellent performances originate from the synergistic mechanism between $\mathrm{BaTiO}_{3}$ macroparticles and $\mathrm{Al}_{2} \mathrm{O}_{3}$ nanoparticles.
\end{abstract}

Keywords: thermal conductivity; dielectric properties; synergistic effect; polymer composites; ceramic

\section{Introduction}

Ever-increasing demands of modern microelectromechanical systems and high-temperature electronic and energy storage devices have stimulated the research and design on multifunctional polymer composites [1-7]. Although polymers such as polypropylene (PP) exhibit excellent processability, insulativity, and are low-cost [8-10], the lack of dielectric properties restricts their application in dielectric materials and electronic component fields [3-5]. In the meantime, dielectric ceramic/polymer composites have received special attention due to their excellent combination of processability and the high dielectric performance of polymer and ceramic [11,12]. However, the miniaturization of electronic devices and the low heat resistance of the polymer matrix often causes difficulty in heat dissipation [1,3], and weaken the operation's reliability of polymer composites 
at high temperature. As such, it is crucial to design and prepare a high thermal-conductive and high dielectric-polymer composite that can solve the heat problem $[1,3,9]$, and retain the ideal electrical or dielectric performances at desired levels $[1,2,13]$.

To improve the thermal properties, high thermal conductivity fillers, such as aluminum oxide $\left(\mathrm{Al}_{2} \mathrm{O}_{3}\right)$ [14,15], boron nitride (BN) [16-19], silicon nitride $\left(\mathrm{Si}_{3} \mathrm{~N}_{4}\right)$ [20,21], and aluminum nitride (AIN) $[22,23]$ etc. are added into the polymer matrices. However, a number of studies indicate that higher thermal conductivity or excellent dielectric property is always accompanied by high filler content $[24,25]$ such as high thermal conductivity filler $\mathrm{Al}_{2} \mathrm{O}_{3}[14,15,26]\left(f_{\text {thermal-conductive filler }}>50 \%\right)$ or high dielectric filler [4] such as $\mathrm{BaTiO}_{3}(\mathrm{BT})$ ceramic $[24,25,27]\left(f_{\text {dielectric filler }}>50 \%\right)$ to achieve the corresponding properties, and over load of various fillers $\left(f_{\text {fillers }}>50 \%\right.$ ) will greatly reduce processability and mechanical properties of the composite [21,28-30], and limited its applications scope. As a result, the overall thermal conductivity, dielectric properties, and mechanical properties etc. of the polymer composite are significantly affected within the polymer composite.

Recently, the use of thermal-conductive polymer composites filled with various inorganic fillers is growing up. For enhancement of the thermal conductivity, the composites are filled with different-scale particle fillers, which can form thermal-conductive connect chains or nets $[18,31]$ among various size particles [32,33] with their compact packed contacts.

For those high thermal conductivity composites filled with different-sized particle fillers, it is possible to obtain high dielectric properties simultaneously if the larger particle size fillers are replaced by the same-sized high dielectric ceramic fillers. Meanwhile, the high thermal conductivity can be retained at a low filler content.

In addition, $\mathrm{BaTiO}_{3}$ and $\mathrm{Al}_{2} \mathrm{O}_{3}$ composites and devices have recently been reported as novel metamaterials [34-38], which can be applied in optical cloaking [39] and biochemical sensing [36,40-44] and detection [41,42], protein analysis [45], food quality analysis, and telecommunication [46], etc. They can also be used in tumor treatment, and radar cross-section reduction $[46,47]$ as a therapeutic tool or a polarization conversion device due to their unique dielectric and electromagnetic properties [48]. This paper is focused on the enhancement of both the thermal conductivity and dielectric properties in series of alumina/barium titanate/polypropylene $\left(\mathrm{Al}_{2} \mathrm{O}_{3} / \mathrm{BT} / \mathrm{PP}\right)$ composites with various volume ratios of $\mathrm{Al}_{2} \mathrm{O}_{3}$ and $\mathrm{BT}$. It is found that the highest thermal conductivity of the composites could be observed when the volume fraction of high thermal conductive filler is at a low level $\left(f_{\mathrm{Al}_{2} \mathrm{O}_{3}}=10 \%\right)$. It is 4.5 times higher than that of the counterpart $\mathrm{Al}_{2} \mathrm{O}_{3} / \mathrm{PP}$ composites, and 5.3 times higher than that of pure PP. Improvement is achieved by the synergistic effect [33] in different-sized $\mathrm{Al}_{2} \mathrm{O}_{3}$ and BT particles in one polymer matrix. Meanwhile, higher dielectric properties are also obtained in the composite. The experimental results reveal a novel approach for the design and preparation of multifunctional polymer composites with different fillers, open many new research areas and lead to lots of novel applications in electromagnetic, optical cloaking [49] with metamaterials [50].

\section{Materials and Methods}

\subsection{Materials}

Polypropylene (PP) powder is prepared via the dissolution/precipitation method and is supplied by the Samsung Total Company HJ730, Seoul, Korea. $\mathrm{Al}_{2} \mathrm{O}_{3}$ is purchased from Aladdin Industrial Corporation, Shanghai, China and is used as soon as it is received. $\mathrm{BaTiO}_{3}(\mathrm{BT})$, which is usually used to improve the properties of dielectric, is supplied by Dianyang Company, Shanghai, China. The physical properties of $\mathrm{Al}_{2} \mathrm{O}_{3}, \mathrm{BT}$ and PP powders used in this study are given in Table 1. 
Table 1. The physical properties of $\mathrm{Al}_{2} \mathrm{O}_{3}, \mathrm{BaTiO}_{3}$ particles, and PP powder.

\begin{tabular}{cccccc}
\hline Materials & $\begin{array}{c}\text { Average } \\
\text { Particle Size } \\
(\boldsymbol{\mu m})\end{array}$ & $\begin{array}{c}\text { Density } \\
\mathbf{( g / \mathbf { c m } ^ { 3 } )}\end{array}$ & $\begin{array}{c}\text { Dielectric } \\
\text { Constant @ } \\
\mathbf{1 0 0 0 ~} \mathbf{~ H z}\end{array}$ & $\begin{array}{c}\text { Breakdown } \\
\text { Strength } \\
\mathbf{( k V / m m})\end{array}$ & $\begin{array}{c}\text { Thermal } \\
\text { Conductivity } \\
\mathbf{( W / m} \cdot \mathbf{K})\end{array}$ \\
\hline $\mathrm{Al}_{2} \mathrm{O}_{3}$ & 0.1 & 4.00 & 10 & 15 & 42 \\
$\mathrm{BT}$ & 3 & 5.85 & 1000 & 3 & 6.2 \\
$\mathrm{PP}$ & - & 0.92 & 2.5 & 30 & 0.14 \\
\hline
\end{tabular}

\subsection{Preparation of PP Powders}

The PP granules are produced by dissolving in the dimethylbenzene solvent with a mass ratio of 1:40. The solvent is kept stirring for $3 \mathrm{~h}$ at $160{ }^{\circ} \mathrm{C}$, and then cooled in the oven at $70{ }^{\circ} \mathrm{C}$. Finally, the PP powders are achieved.

\subsection{Preparation of Composite Sample}

The $\mathrm{Al}_{2} \mathrm{O}_{3} / \mathrm{BT} / \mathrm{PP}, \mathrm{Al}_{2} \mathrm{O}_{3} / \mathrm{PP}$, and $\mathrm{BT} / \mathrm{PP}$ composites, $12 \mathrm{~mm}$ in diameter and $1.2-2 \mathrm{~mm}$ in thickness, are prepared from $\mathrm{PP}, \mathrm{Al}_{2} \mathrm{O}_{3}$, or $\mathrm{BT}$ powders by adopting a simple blending and hot-pressing procedure at about $170-190{ }^{\circ} \mathrm{C}$ and $15-20 \mathrm{MPa}$ for $30 \mathrm{~min}$ in a die. Finally, the samples are coated with a silver paste.

\subsection{Characterizations}

A C-THERM Thermal Conductivity Analyzer is used to measure the out-of-plane thermal conductivity of cylindrical samples of $\mathrm{Al}_{2} \mathrm{O}_{3} / \mathrm{BT} / \mathrm{PP}$ composites, which are $12 \mathrm{~mm}$ in diameter and $1.2-2 \mathrm{~mm}$ in thickness.

The values of dielectric properties and capacitance of the composites are obtained by using an Agilent-4980A impedance analyzer. Frequency range [51] is $100 \mathrm{~Hz}-2 \mathrm{MHz}$ at an average voltage of $0.5 \mathrm{~V}$. The relative dielectric constant $\left(\varepsilon_{\mathrm{r}}\right)$ is calculated according to Equation (1):

$$
\varepsilon_{\mathrm{r}}=\frac{C \times d}{\varepsilon_{0} \times A}
$$

$C$ is the capacitance of the composite, $d$ is the thickness of the discs $(m), \varepsilon_{0}$ is the vacuum dielectric constant $\left(8.854 \times 10^{-12} \mathrm{~F} \cdot \mathrm{m}^{-1}\right)$, and $\mathrm{A}$ is the area of the major disc surface $\left(\mathrm{m}^{2}\right)$.

The Maxwell Garnett Equation (2) [52] and logarithmic mixing Equation (3) [53] is used for calculating the theoretical dielectric constant in 0-3 type polymer composites

$$
\varepsilon_{\text {eff }}=\varepsilon_{1}+3 f \varepsilon_{1} \frac{\varepsilon_{2}-\varepsilon_{1}}{\varepsilon_{2}+2 \varepsilon_{1}-f\left(\varepsilon_{2}-\varepsilon_{1}\right)}
$$

where $f$ represents volume fraction of the filler in the composite, while $\varepsilon_{2}$ and $\varepsilon_{1}$ are the dielectric constants of the filler and the polymer matrix, respectively,

$$
\log \varepsilon=\log \varepsilon_{\text {polymer }}+f_{\text {filler }} \log \left(\varepsilon_{\text {filler }} / \varepsilon_{\text {polymer }}\right)
$$

where $f_{\text {filler }}$ represented volume fraction of the filler in the composite, $\varepsilon_{\text {filler }}$ and $\varepsilon_{\text {polymer }}$ are the dielectric constants of the filler and the polymer matrix, respectively.

The cross-sectional morphology pictures are made with a Japanese JEOL Hitachi S-530 scanning electron microscope (SEM, Japan Hitachi, Tokyo, Japan) at an acceleration voltage of $3 \mathrm{kV}$ and a magnification of 5000 times and 10,000 times respectively. The images of cross-section of the composites are compared. The sample is coated with a conductive adhesive in the metal sample stage. 
The breakdown strength measurement is conducted by using a dielectric strength tester (made by DH, Shanghai Lanpotronics Co., Shanghai, China). It is performed at room temperature using a DC voltage. Test voltage with ramp rate $2 \mathrm{~V} / \mathrm{s}$ is applied.

\section{Results and Discussion}

\subsection{Thermal Conductivity of the Composites}

Mostly PP composites or organic/inorganic blends are able to keep good mechanical performance with their total filler content $f_{\text {fillers }} \leq 50 \%$, which has been reported in previous papers [28-30], therefore, the PP volume fraction is held as a constant at 50\% $\left(f_{\mathrm{PP}}=50 \%\right)$ in our experiments for maintaining a desirable processability and the mechanical properties, and a series of $\mathrm{Al}_{2} \mathrm{O}_{3} / \mathrm{BT} / \mathrm{PP}, \mathrm{Al}_{2} \mathrm{O}_{3} / \mathrm{PP}$ and $\mathrm{BT} / \mathrm{PP}$ composites with various volume fractions of $\mathrm{Al}_{2} \mathrm{O}_{3}$ and $\mathrm{BT}$ particles are prepared. Thermal conductivities of these composites are shown in Figure $1 \mathrm{a}, \mathrm{b}$. As for $\mathrm{Al}_{2} \mathrm{O}_{3} / \mathrm{PP}$ or $\mathrm{BT} / \mathrm{PP}$ binary composites, the thermal conductivities had been at a low level $\left(\leq 0.35 \mathrm{~W} / \mathrm{m} \cdot \mathrm{K}, f_{\mathrm{Al}_{2} \mathrm{O}_{3}}\right.$ or $\left.f_{\mathrm{BT}} \leq 50 \%\right)$ before volume fraction of $\mathrm{Al}_{2} \mathrm{O}_{3}$ (or BT) particles increased from $10 \%$ to $50 \%$. While comparing $\mathrm{BT} / \mathrm{PP}$ and $\mathrm{Al}_{2} \mathrm{O}_{3} / \mathrm{PP}$ composites with same volume fraction, an abnormal thermal conductivity is found: the BT/PP composites actually present a relatively higher thermal conductivity (differ by no more than $0.10 \mathrm{~W} / \mathrm{m} \cdot \mathrm{K}$ ) than that of the $\mathrm{Al}_{2} \mathrm{O}_{3} / \mathrm{PP}$ composite, which is highly thermal-conductive.
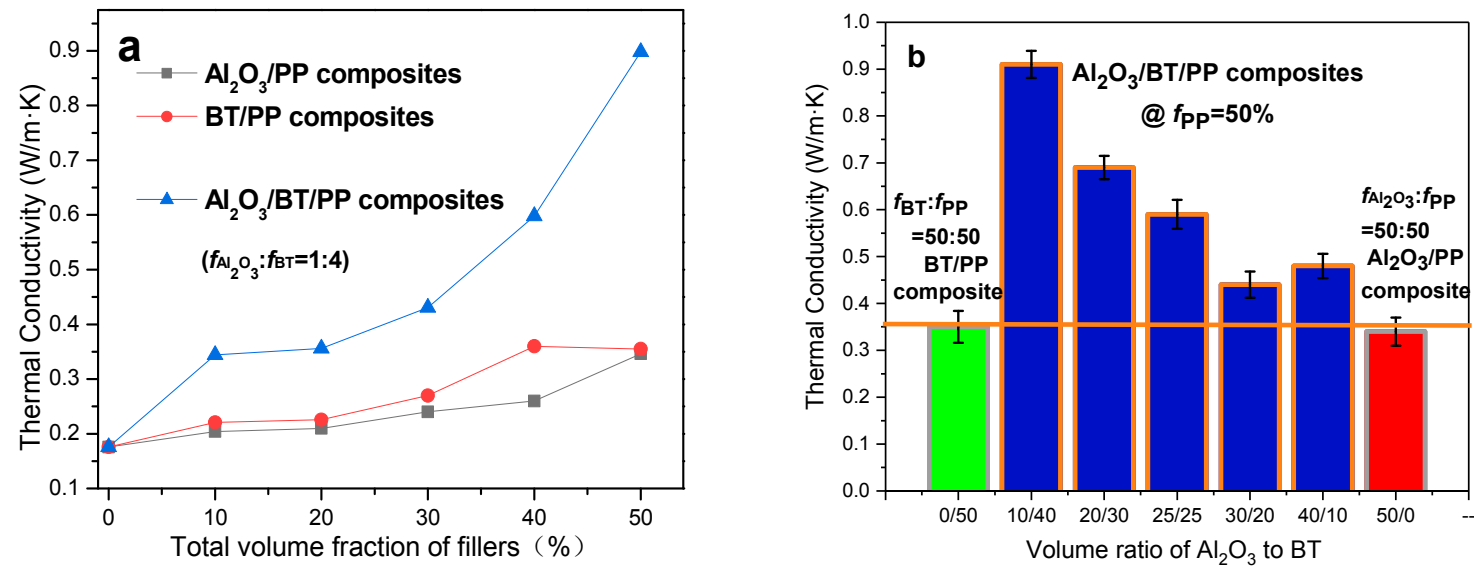

Figure 1. Thermal conductivity of the composites: (a) $\mathrm{Al}_{2} \mathrm{O}_{3} / \mathrm{PP}, \mathrm{BT} / \mathrm{PP}$ and $\mathrm{Al}_{2} \mathrm{O}_{3} / \mathrm{BT} / \mathrm{PP}$ composites; (b) $\mathrm{Al}_{2} \mathrm{O}_{3} / \mathrm{BT} / \mathrm{PP}$ composites.

In addition, the evaluation of the heat-conducting property of $\mathrm{Al}_{2} \mathrm{O}_{3} / \mathrm{BT} / \mathrm{PP}$ composites yielded remarkable results: the thermal conductivity of $\mathrm{Al}_{2} \mathrm{O}_{3} / \mathrm{BT} / \mathrm{PP}$ ternary composites is significantly higher $(0.45-0.90 \mathrm{~W} / \mathrm{m} \cdot \mathrm{K}$, Figure $1 \mathrm{~b})$ compared with $\mathrm{Al}_{2} \mathrm{O}_{3} / \mathrm{PP}$ or BT/PP binary composites $(0.17-0.35 \mathrm{~W} / \mathrm{m} \cdot \mathrm{K})$, and increased with the decrease of $f_{\mathrm{Al}_{2} \mathrm{O}_{3}}$, i.e., the lower the $f_{\mathrm{Al}_{2} \mathrm{O}_{3}}$ is, the higher the thermal conductivity is. And it is also found that the $\mathrm{Al}_{2} \mathrm{O}_{3} / \mathrm{BT} / \mathrm{PP}$ composites reached its maximum thermal conductivity value $(0.90 \mathrm{~W} / \mathrm{m} \cdot \mathrm{K})$ with lowest thermal conductive filler content $\left(f_{\mathrm{Al}_{2} \mathrm{O}_{3}}=10 \%\right)$. This maximum value was 5.3 times higher than that of pure $\mathrm{PP}(0.17 \mathrm{~W} / \mathrm{m} \cdot \mathrm{K})$, and 4.5 times higher than its counterpart $\mathrm{Al}_{2} \mathrm{O}_{3} / \mathrm{PP}$ composite $\left(0.20 \mathrm{~W} / \mathrm{m} \cdot \mathrm{K}, f_{\mathrm{Al}_{2} \mathrm{O}_{3}}: f_{\mathrm{PP}}=10: 90\right)$. The obviously synergistic effect on thermal conductivity is found in all the $\mathrm{Al}_{2} \mathrm{O}_{3} / \mathrm{BT} / \mathrm{PP}$ composites (Figure 1b) with different ratios, and the lower the $f$ thermal-conductive filler, the higher the thermal conductivity.

\subsection{The Micrographs of $\mathrm{Al}_{2} \mathrm{O}_{3} / \mathrm{BT} / \mathrm{PP}, \mathrm{Al}_{2} \mathrm{O}_{3} / \mathrm{PP}$ and $\mathrm{BT} / \mathrm{PP}$ Composites}

The thermal conductivity of polymer matrix composites are affected not only by the inherent thermal properties, but also by many other factors, such as shape, size, distribution, particle content and composite microstructure [33]. The mixed fillers with different volume ratios and particle sizes are 
used in this study, which may develop into unusual microstructures in $\mathrm{Al}_{2} \mathrm{O}_{3} / \mathrm{BT} / \mathrm{PP}, \mathrm{Al}_{2} \mathrm{O}_{3} / \mathrm{PP}$ and $\mathrm{BT} / \mathrm{PP}$ composites [54]. Figure 2 shows the SEM images of the fracture cross-section of $\mathrm{Al}_{2} \mathrm{O}_{3} / \mathrm{BT} / \mathrm{PP}$ $\left(f_{\mathrm{Al}_{2} \mathrm{O}_{3}}: f_{\mathrm{BT}}: f_{\mathrm{PP}}=10: 40: 50\right), \mathrm{Al}_{2} \mathrm{O}_{3} / \mathrm{PP}\left(f_{\mathrm{Al}_{2} \mathrm{O}_{3}}: f_{\mathrm{PP}}=50: 50\right)$ and BT $/$ PP composites $\left(f_{\mathrm{BT}}: f_{\mathrm{PP}}=50: 50\right)$.
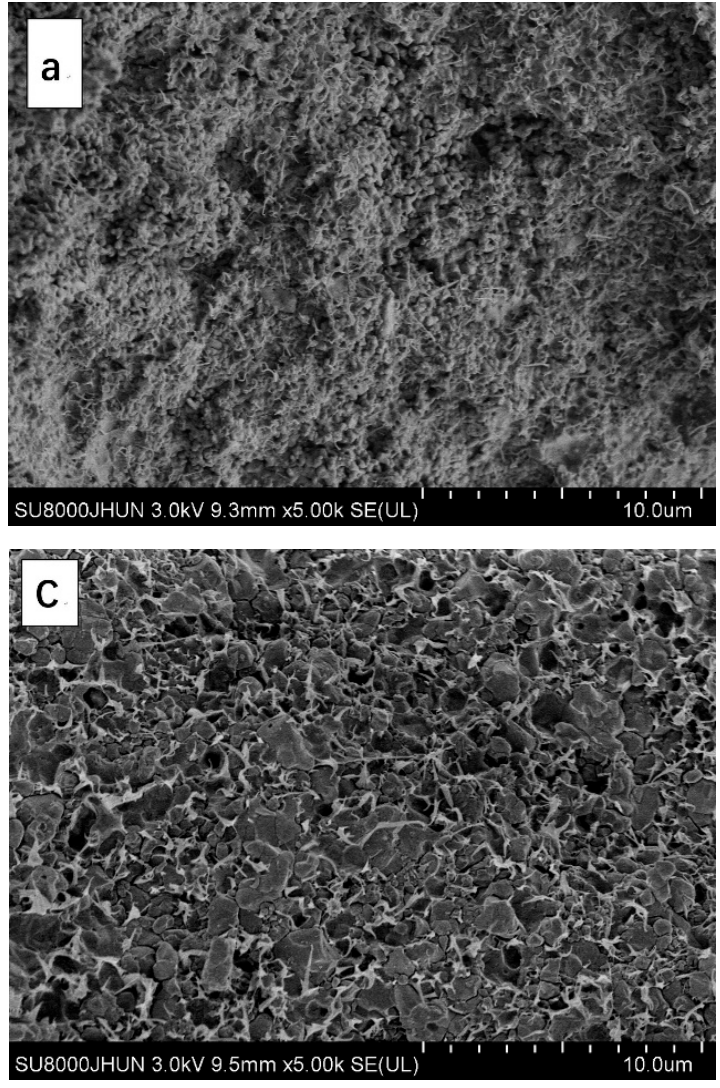
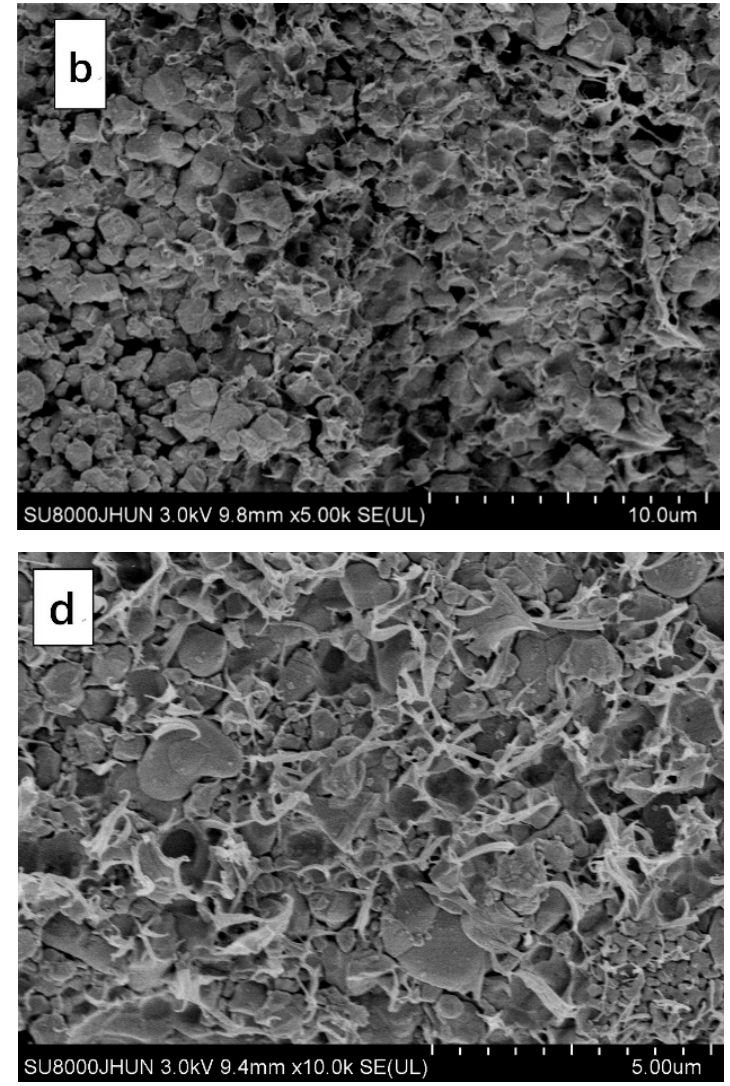

Figure 2. SEM micrographs of the fracture cross-section of the composites: (a) $f_{\mathrm{Al}_{2} \mathrm{O}_{3}}: f_{\mathrm{PP}}=50: 50$ $\mathrm{Al}_{2} \mathrm{O}_{3} /$ PP composite; (b) $f_{\mathrm{BT}}: f_{\mathrm{PP}}=50: 50 \mathrm{BT} / \mathrm{PP}$ composite; (c,d) $f_{\mathrm{Al}_{2} \mathrm{O}_{3}}: f_{\mathrm{BT}}: f_{\mathrm{PP}}=10: 40: 50 \mathrm{Al}_{2} \mathrm{O}_{3} / \mathrm{BT} / \mathrm{PP}$ composite in different magnifications.

In Figure $2 \mathrm{a}$, nanoscale $\mathrm{Al}_{2} \mathrm{O}_{3}$ thermal-conductive particles are dispersed uniformly in the PP matrix. However, the thermal insulation polymer-PP-blocks the interconnection among $\mathrm{Al}_{2} \mathrm{O}_{3}$ particles and thus breaks up the extension of thermal conductive chains. On the contrary, from the micrograph of BT/PP composite in Figure 2b, it can be seen that although large number of voids and holes existed in low thermal-conductive BT/PP composites, the micrometer-scale BT particles, which are bigger than $\mathrm{Al}_{2} \mathrm{O}_{3}$ particles, make it easier for them to touch each other to form a heat conducting network [55], which leading to relatively higher thermal conductivity of BT/PP composites than that of $\mathrm{Al}_{2} \mathrm{O}_{3} / \mathrm{PP}$ composites. These results suggest the compact connection or arrangement of filler particles is more advantageous to improve thermal conductive property.

A stronger phenomena can be seen from Figure 2c, which shows the micromorphology of $\mathrm{Al}_{2} \mathrm{O}_{3} / \mathrm{BT} / \mathrm{PP}$ composite $\left(f_{\mathrm{Al}_{2} \mathrm{O}_{3}}: f_{\mathrm{BT}}: f_{\mathrm{PP}}=10: 40: 50\right)$, where the voids and holes in the BT/PP composite disappeared. Instead, more homogeneous dispersion and more compact interface connection of BT and $\mathrm{Al}_{2} \mathrm{O}_{3}$ particles in PP matrix are observed.

Further investigation of magnified $\mathrm{Al}_{2} \mathrm{O}_{3} / \mathrm{BT} / \mathrm{PP}$ SEM micrograph (Figure 2d) indicate that the BT macroparticles are able to break down $\mathrm{Al}_{2} \mathrm{O}_{3}$ nanoparticle aggregations, thereby allowing $\mathrm{Al}_{2} \mathrm{O}_{3}$ nanoparticle to form the homogeneous dispersion with smaller size in a polymer matrix, and surround the big BT particles. The dispersion uniformity of $\mathrm{Al}_{2} \mathrm{O}_{3}$ and $\mathrm{BT}$ particles is verified again using energy dispersive spectrometer (EDS) of $\mathrm{Al}$ and Ba elementals. As shown in Figure 3, the Ba and $\mathrm{Al}$ element 
distribution diagrams demonstrated the uniform dispersion of plenty of BT particles in the polymer matrix, and the $\mathrm{Al}$ element formed many curves and nets at the same time; in the overlap of the two images, the compact structure between $\mathrm{Al}_{2} \mathrm{O}_{3}$ and $\mathrm{BT}$ particles are observed.
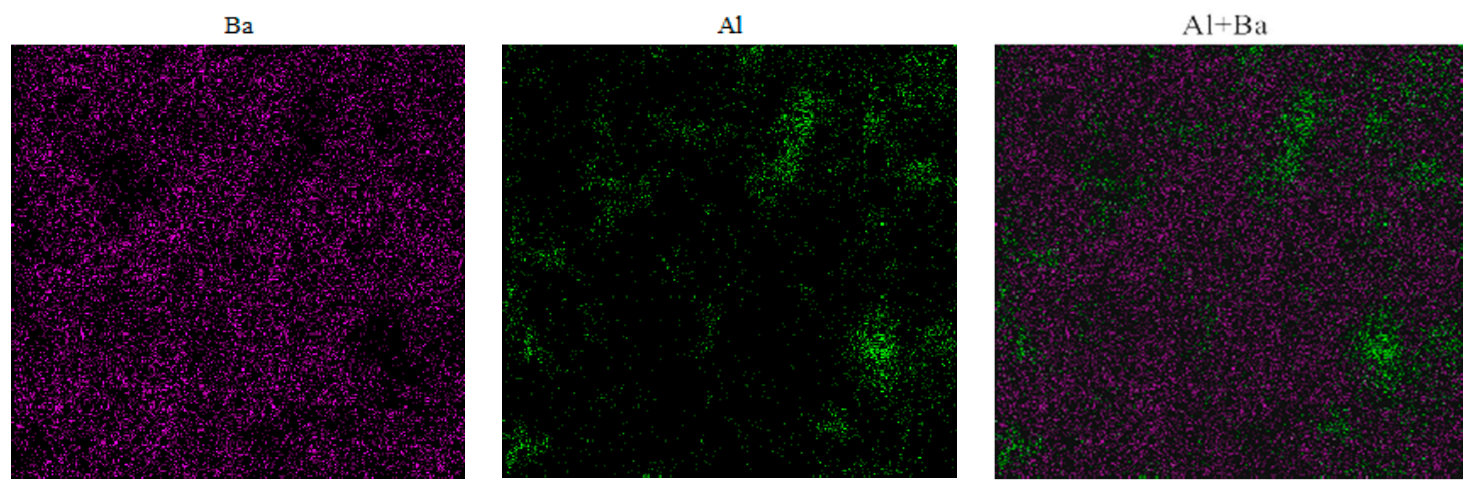

Figure 3. The EDS of $\mathrm{Al}$, $\mathrm{Ba}$ and $\mathrm{Al}+\mathrm{Ba}$ elemental in $f_{\mathrm{Al}_{2} \mathrm{O}_{3}}: f_{\mathrm{BT}}: f_{\mathrm{PP}}=10: 40: 50 \mathrm{Al}_{2} \mathrm{O}_{3} / \mathrm{BT} / \mathrm{PP}$ composite.

The synergistic mechanism of thermal conductivity in $\mathrm{Al}_{2} \mathrm{O}_{3} / \mathrm{BT} / \mathrm{PP}$ composite is further illustrated in Figure 4. When $f_{\mathrm{BT}}$ is less than $40 \%$, the holes and voids among BT particles are large enough. It leads to the loose distribution of $\mathrm{Al}_{2} \mathrm{O}_{3}$ nanoparticles and their agglomerations, which are easily wrapped up by heat-insulated PP matrix (Figure 4a), and cause lower thermal conductivity as shown in Figures $1 \mathrm{~b}$ and $4 \mathrm{~b}$. As the content of the BT particles increased, voids and holes between BT particles became narrower and smaller, and the smaller thermal-conductive nano- $\mathrm{Al}_{2} \mathrm{O}_{3}$ particles are forced to be directionally arranged and disperse along the fixed voids formed by BT macroparticles. As a result, many slim and compact $\mathrm{Al}_{2} \mathrm{O}_{3}$ thermal conductive chains and nets are formed.

When the ration of $f_{\mathrm{BT}}: f_{\mathrm{Al}_{2} \mathrm{O}_{3}}$ increased to $40: 10$, the thermal conductivity further increase and reached the highest value due to more compact connection between thermal conductive $\mathrm{Al}_{2} \mathrm{O}_{3}$ nanoparticles with smaller size. Therefore, the thermal conductivity of $\mathrm{Al}_{2} \mathrm{O}_{3} / \mathrm{BT} / \mathrm{PP}$ composites is greatly enhanced even at a lower thermal conductive filler content (Figure 4a), i.e., synergistic effect, and further demonstrated that the compact and directional connection of filler particles played a key role in improving the composite thermal conductivity.
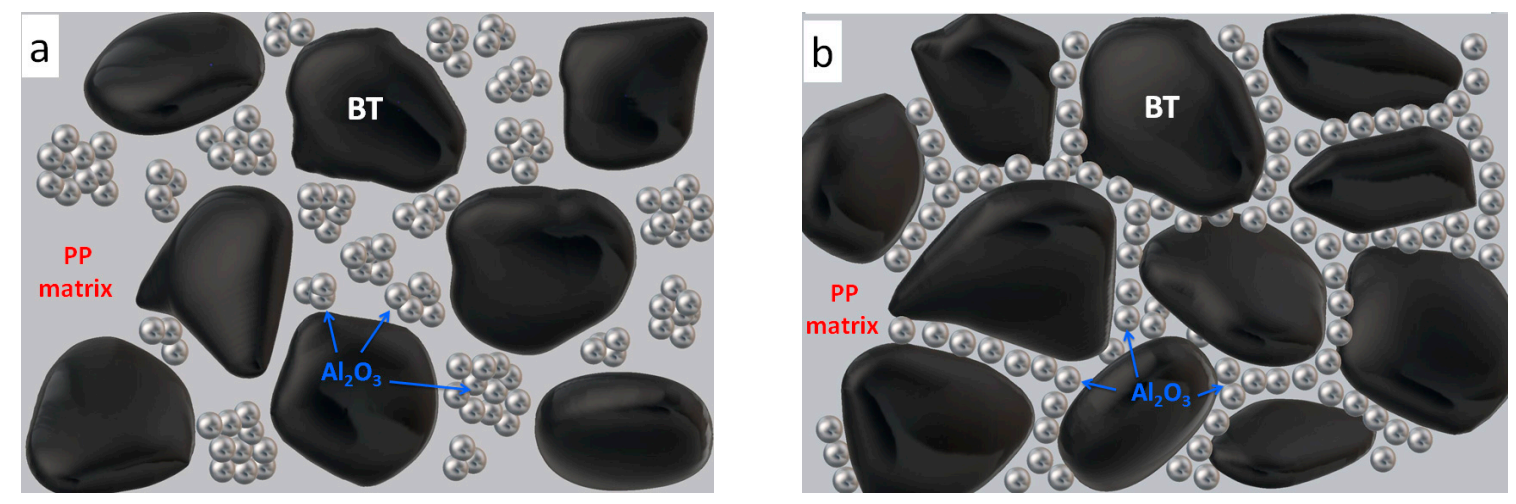

Figure 4. The schematic diagram of synergistic mechanism of thermal conductivity in $f_{\mathrm{PP}}=50 \%$ $\mathrm{Al}_{2} \mathrm{O}_{3} / \mathrm{BT} /$ PP composites: (a) $f_{\mathrm{BT}}: f_{\mathrm{Al}_{2} \mathrm{O}_{3}}=40: 10$; (b) $f_{\mathrm{BT}}: f_{\mathrm{Al}_{2} \mathrm{O}_{3}}<40: 10$.

\subsection{Dielectric Properties of the Composites}

Dielectric properties are closely related to the filling content and distribution [54] of dielectric particles in ceramic/polymer composites. As shown in Figure 5, the dielectric constant of $\mathrm{Al}_{2} \mathrm{O}_{3} / \mathrm{PP}$, $\mathrm{BT} / \mathrm{PP}$ and $\mathrm{Al}_{2} \mathrm{O}_{3} / \mathrm{BT} / \mathrm{PP}$ composites increase with filler content; in Figure $6 \mathrm{a}, \mathrm{b}$, the dielectric constant 
$\left(\varepsilon_{\mathrm{r}}\right.$, at $1000 \mathrm{~Hz}$ ) of $\mathrm{Al}_{2} \mathrm{O}_{3} / \mathrm{BT} / \mathrm{PP}$ composites increased in accordance with BT volume, reaching the highest value of $\varepsilon_{\mathrm{r}}=18$ at $f_{\mathrm{BT}}=40 \%$, which is higher than that of corresponding $\mathrm{Al}_{2} \mathrm{O}_{3} / \mathrm{PP}$ composites and pure PP $\left(\varepsilon_{\mathrm{r}}<5.0\right)$, and there is no obviously decrease in $\varepsilon_{\mathrm{r}}$ compared with corresponding BT/PP composites $\left(\varepsilon_{\mathrm{r}}=20\right.$ at $\left.f_{\mathrm{BT}}: f_{\mathrm{PP}}=40: 60\right)$. Meanwhile, the dielectric loss (tan, Figures $5 \mathrm{f}$ and $\left.6 \mathrm{~b}\right)$ of $\mathrm{Al}_{2} \mathrm{O}_{3} / \mathrm{BT} / \mathrm{PP}$ composites keep at a lower level $(\tan \delta<0.030$ at $1000 \mathrm{~Hz})$ when compared with corresponding $\mathrm{BT} / \mathrm{PP}$ composites $(\tan \delta<0.050$ at $1000 \mathrm{~Hz}$ ).
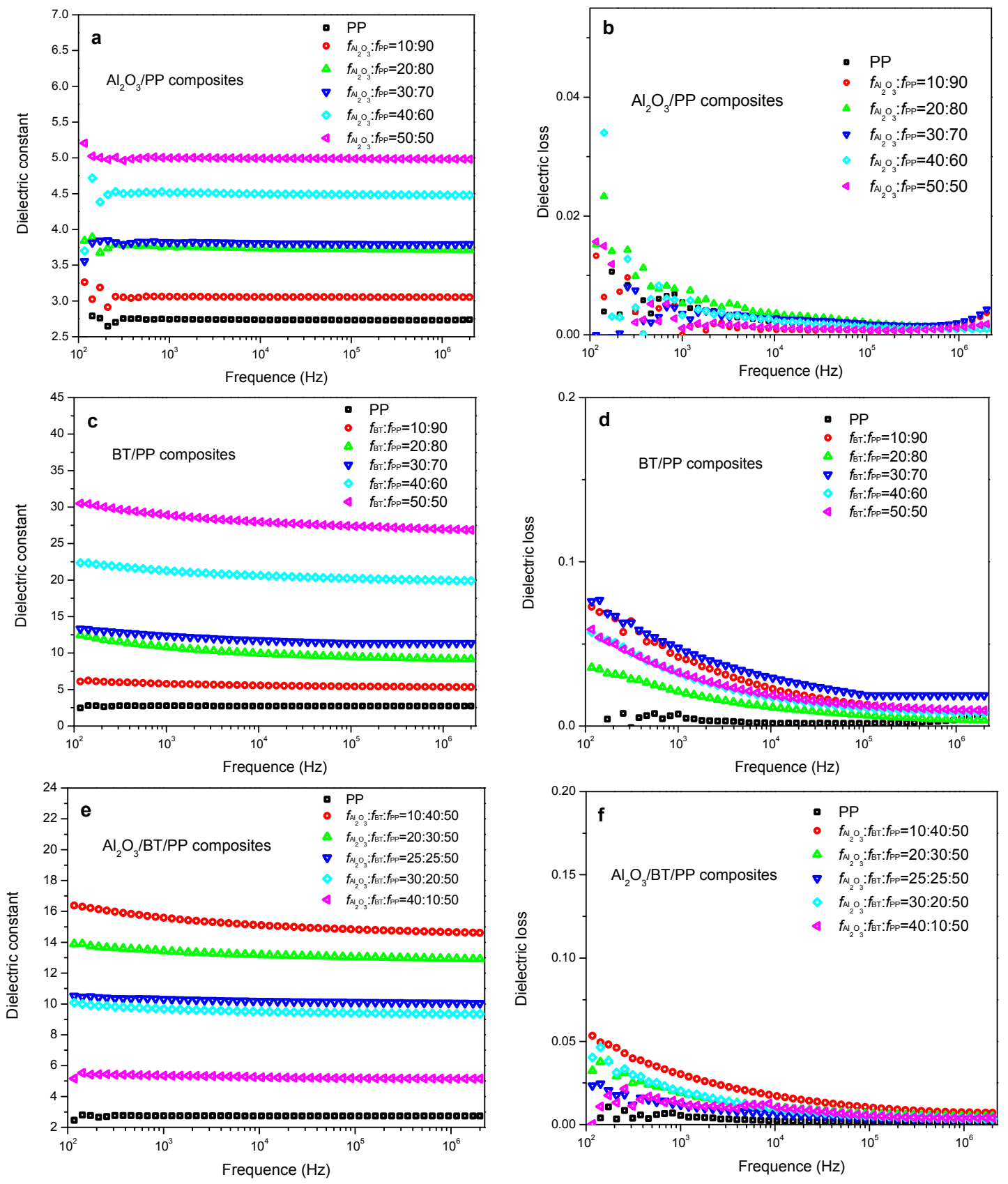

Figure 5. Dielectric constant/loss-frequency curves of $\mathrm{Al}_{2} \mathrm{O}_{3} / \mathrm{PP}, \mathrm{BT} / \mathrm{PP}$ and $\mathrm{Al}_{2} \mathrm{O}_{3} / \mathrm{BT} / \mathrm{PP}$ composites from $100 \mathrm{~Hz}$ to $2 \mathrm{MHz}$ : (a,b) $\mathrm{Al}_{2} \mathrm{O}_{3} / \mathrm{PP}$ composites; (c,d) BT/PP composites; and (e,f) $\mathrm{Al}_{2} \mathrm{O}_{3} / \mathrm{BT} / \mathrm{PP}$ composites. 
The Maxwell Garnett Equation (2) is selected as the theoretical model due to its wide application in BT-loaded cloaking metamaterials and 0-3 type connectivity BT/PP, however, the calculated dielectric constant value is much lower than the measured value (one-third of measured value at $f_{\mathrm{BT}}: f_{\mathrm{PP}}=50: 50$, Figure 6a). On the other hand, the logarithmic mixing Equation (3) applied in BT/cyanoethylated cellulose composites is more suitable for 0-3 type high-dielectric polymer composites (Figure 6a). Although the measured results of $\mathrm{BT} / \mathrm{PP}$ and $\mathrm{Al}_{2} \mathrm{O}_{3} / \mathrm{BT} / \mathrm{PP}$ composites are slightly lower than the theoretical values of $\mathrm{BT} / \mathrm{PP}$, the measured dielectric constant of $\mathrm{BT} / \mathrm{PP}$ and $\mathrm{Al}_{2} \mathrm{O}_{3} / \mathrm{BT} / \mathrm{PP}$ composites fit the logarithmic mixing model well. A more exact model for multiphase high-dielectric polymer composites will be discussed in later work.

High dielectric constant and low dielectric loss are simultaneously observed in $\mathrm{Al}_{2} \mathrm{O}_{3} / \mathrm{BT} / \mathrm{PP}$ composites, and these optimal dielectric properties are attributed to high filling volume and uniform dispersion of BT particles, from the synergistic mechanism between $\mathrm{BT}$ macroparticles and $\mathrm{Al}_{2} \mathrm{O}_{3}$ nanoparticles. The presented material is facilely prepared using simply hot-express technology, and exhibit higher dielectric constant and higher thermal conductivity simultaneously, that urgently needed in modern energy storage and high temperature dielectric devices.
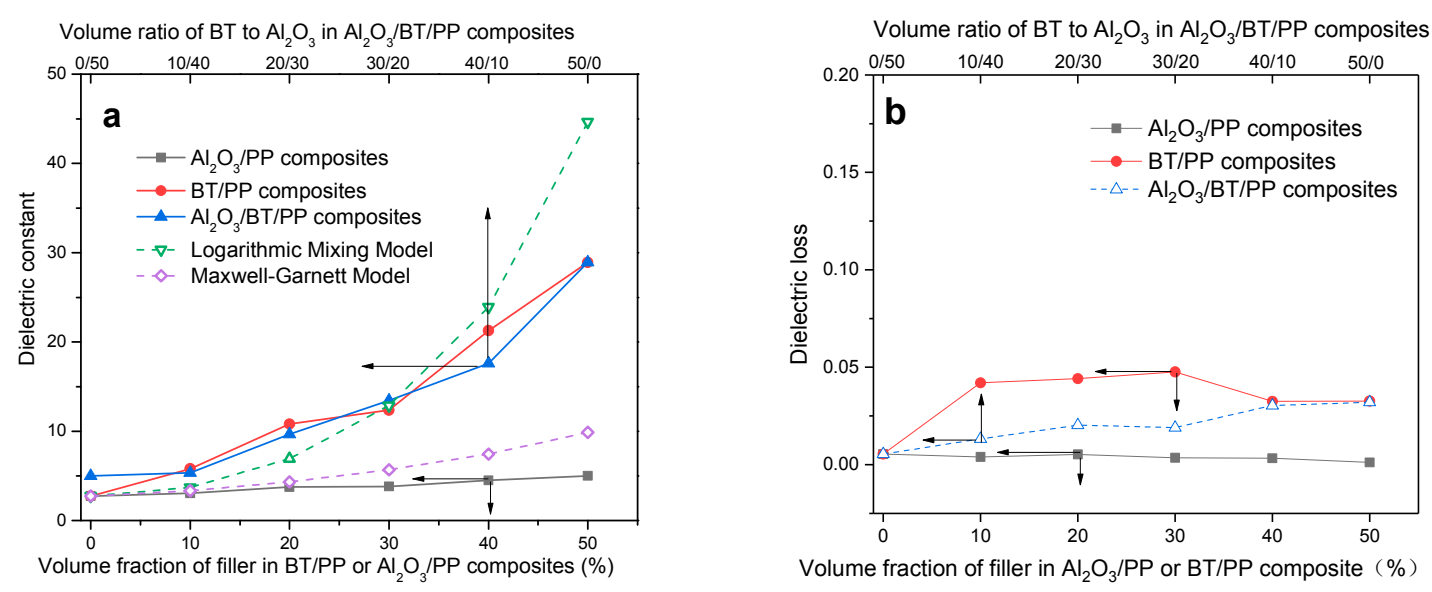

Figure 6. Dielectric properties of $\mathrm{Al}_{2} \mathrm{O}_{3} / \mathrm{BT} / \mathrm{PP}, \mathrm{Al}_{2} \mathrm{O}_{3} / \mathrm{PP}$ and BT/PP composites with different $f_{\text {filler }}$ @ $1000 \mathrm{~Hz}$ : (a) dielectric constant of the composites; (b) dielectric loss of the composites.

\subsection{Breakdown Strength of the Composites}

For dielectric and insulate polymer composites, breakdown strength $\left(E_{\mathrm{b}}\right)$ could largely affect their operating electric field $[56,57]$, which was influenced by many factors, including the $E_{\mathrm{b}}$ of filler and polymer matrix, and the distribution of filler particles and their interconnection in composites. Figure 7a,b shows the Weibull breakdown strength of the composites with different filler content. It can be seen that the addition of BT particles improved the breakdown strength of the composites, while the $\mathrm{Al}_{2} \mathrm{O}_{3}$ particles played an opposite role.

Although the $E_{\mathrm{b}}$ of $\mathrm{BT}$ is lower than that of $\mathrm{Al}_{2} \mathrm{O}_{3}$, the composites $E_{\mathrm{b}}$ mainly depend on the $\mathrm{BT}$ and $\mathrm{Al}_{2} \mathrm{O}_{3}$ particles distribution and interconnection, and this abnormal phenomenon is attributable to the more compact interconnection and homogeneous dispersion of $\mathrm{Al}_{2} \mathrm{O}_{3}$ and $\mathrm{BT}$ particles in polymer matrix. 

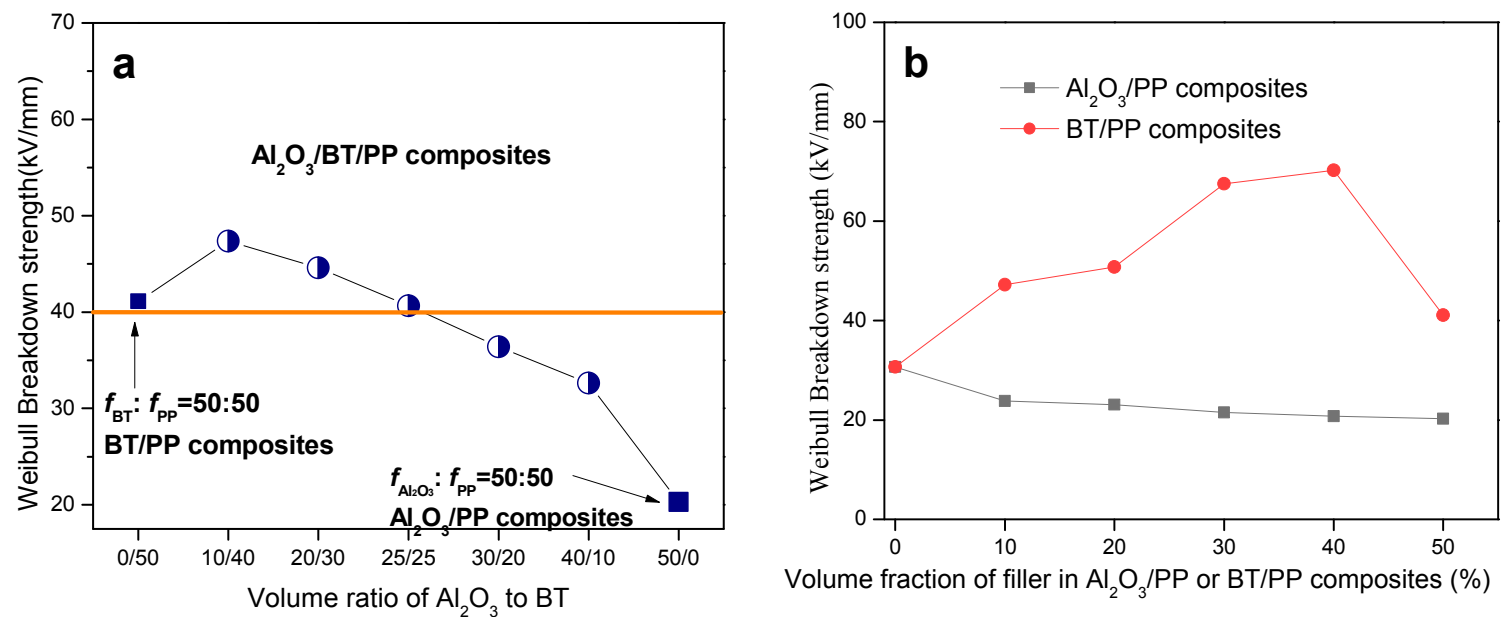

Figure 7. Weibull breakdown strength of the composites as a function of filler content: (a) $\mathrm{Al}_{2} \mathrm{O}_{3} / \mathrm{BT} / \mathrm{PP}$ composites; (b) $\mathrm{Al}_{2} \mathrm{O}_{3} / \mathrm{PP}$ and $\mathrm{BT} / \mathrm{PP}$ composites.

For $\mathrm{Al}_{2} \mathrm{O}_{3} / \mathrm{BT} / \mathrm{PP}$ composites, the value of Weibull $E_{\mathrm{b}}$ increase with the content of $\mathrm{BT}$, and reached its peak value about $47.35 \mathrm{kV} / \mathrm{mm}$ when $f_{\mathrm{BT}}: f_{\mathrm{Al}_{2} \mathrm{O}_{3}}=40: 10$. It is higher than that of both $\mathrm{Al}_{2} \mathrm{O}_{3} / \mathrm{PP}$ composites $\left(20.28 \mathrm{kV} / \mathrm{mm}, f_{\mathrm{BT}}: f_{\mathrm{Al}_{2} \mathrm{O}_{3}}=50: 50\right)$ and $\mathrm{BT} / \mathrm{PP}$ composites $\left(41.11 \mathrm{kV} / \mathrm{mm}, f_{\mathrm{BT}}: f_{\mathrm{PP}}=50: 50\right)$, and even 1.6 times higher than pure $\mathrm{PP}(30.68 \mathrm{kV} / \mathrm{m}$, Figure $7 \mathrm{~b})$. The voltage rise rate applied in this study is $2 \mathrm{~V} / \mathrm{s}$, the electric tree growing slowly inside the composites, and the compact microstructure and homogeneous dispersion of $\mathrm{Al}_{2} \mathrm{O}_{3}$ and BT particles (shown in Figure 2d) restrict the development of this process. So, a synergistic enhancement effect of the thermal conductivity, dielectric strength and dielectric constant is achieved at optimal $f_{\mathrm{Al}_{2} \mathrm{O}_{3}}: f_{\mathrm{BT}}: f_{\mathrm{PP}}$ ratio of 10:40:50.

\section{Conclusions}

In this study, a series of fabricated $\mathrm{Al}_{2} \mathrm{O}_{3} / \mathrm{BT} / \mathrm{PP}$ polymer composites emerged, which not only show significantly increased thermal conductivity but also higher dielectric properties with no more than $50 \%$ filling volume.

It was found that the thermal conductivity of the hybrid $\mathrm{Al}_{2} \mathrm{O}_{3} / \mathrm{BT} / \mathrm{PP}$ composites could be enhanced significantly even when the thermal conductive fillers are kept at a lower volume fraction $\left(f_{\mathrm{Al}_{2} \mathrm{O}_{3}}=10 \%\right)$. The highest thermal conductivity reached $0.90 \mathrm{~W} / \mathrm{m} \cdot \mathrm{K}$, which is 4.5 times higher than that of $\mathrm{Al}_{2} \mathrm{O}_{3} / \mathrm{PP}$ composites and 5.3 times higher than that of pure PP. In addition, high dielectric strength $(47.35 \mathrm{kV} / \mathrm{mm})$, dielectric constant $\left(\varepsilon_{\mathrm{r}}=18\right.$ at $\left.1000 \mathrm{~Hz}\right)$, and low dielectric loss ( $\tan \delta=0.030$ ) are also found in the $\mathrm{Al}_{2} \mathrm{O}_{3} / \mathrm{BT} / \mathrm{PP}$ composite. This improvement came from the strong synergistic collaboration of particles with different sizes and their compact connection and directionally arrangement, making it possible to obtain both high thermal conductivity and high dielectric properties at low filler loading within one polymer matrix.

The experimental results could enhance the high temperature tolerance of PP dielectric materials in energy storage and in a supercapacitor, and revealed a novel approach for the preparation of organic/inorganic polymer composites with multi-function or -phase, which is crucial for the design of modern function composites, integrated electronic systems, and metamaterials [40-47]. The corresponding structure design and device will be further discussed and prepared in future.

Author Contributions: Conceptualization, L.G. and Q.W.; Methodology, J.Y. and L.H.; Writing-Original Draft Preparation, M.Z., L.H.; Writing-Review \& Editing, Z.S. and J.W.; Project Administration, F.Y. and Funding Acquisition, X.J.

Funding: This research is supported by the National Natural Science Foundation of China (NSFC: 51273154), and Natural Science Foundation of Hubei province (2017CFB289). 
Acknowledgments: We acknowledge the support from the National Science Foundation of China (Grant No. 51273154), Natural Science Foundation of Hubei province (No. 2017CFB289) and Open Project Fund of Ministry-of-Education Key Laboratory for the Green Preparation and Application of Functional Materials.

Conflicts of Interest: The authors declare no conflict of interest.

\section{References}

1. Li, Q.; Chen, L.; Gadinski, M.R.; Zhang, S.; Zhang, G.; Li, U.; Iagodkine, E.; Haque, A.; Chen, L.Q.; Jackson, N.; et al. Flexible high-temperature dielectric materials from polymer nanocomposites. Nature 2015, 523, 576-579. [CrossRef] [PubMed]

2. Abdalla, S.; Al-Marzouki, F.; Obaid, A.; Gamal, S. Effect of addition of colloidal silica to films of polyimide, polyvinylpyridine, polystyrene, and polymethylmethacrylate nano-composites. Materials 2016, 9, 104. [CrossRef] [PubMed]

3. Li, Q.; Liu, F.H.; Yang, T.N.; Gadinski, M.R.; Zhang, G.Z.; Chen, L.Q.; Wang, Q. Sandwich-structured polymer nanocomposites with high energy density and great charge-discharge efficiency at elevated temperatures. Proc. Natl. Acad. Sci. USA 2016, 113, 9995-10000. [CrossRef] [PubMed]

4. Yao, J.L.; Xiong, C.X.; Dong, L.J.; Chen, C.; Lei, Y.A.; Chen, L.; Li, R.; Zhu, Q.M.; Liu, X.F. Enhancement of dielectric constant and piezoelectric coefficient of ceramic-polymer composites by interface chelation. J. Mater. Chem. 2009, 19, 2817-2821. [CrossRef]

5. Han, S.; Yang, X.; Zhuang, X.; Yu, J.; Li, L. Tailoring the dielectric layer structure for enhanced performance of organic field-effect transistors: The use of a sandwiched polar dielectric layer. Materials 2016, 9, 545. [CrossRef] [PubMed]

6. Huang, H.; Yao, J.; Liu, Y.; Tuo, X.; Da, Y.; Zeng, X.; Li, L. 3D nanostructured polypyrrole/sodium alginate conducting hydrogel from self-assembly with high supercapacitor performance. J. Macromol. Sci. B 2017, 56, 532-540. [CrossRef]

7. Huang, H.B.; Yao, J.L.; Li, L.; Zhu, F.; Liu, Z.T.; Zeng, X.P.; Yu, X.H.; Huang, Z.L. Reinforced polyaniline/polyvinyl alcohol conducting hydrogel from a freezing-thawing method as self-supported electrode for supercapacitors. J. Mater. Sci. 2016, 51, 8728-8736. [CrossRef]

8. Barshaw, E.J.; White, J.; Chait, M.J.; Cornette, J.B.; Bustamante, J.; Folli, F.; Biltchick, D.; Borelli, G.; Picci, G.; Rabuffi, M. High energy density (HED) biaxially-oriented poly-propylene (BOPP) capacitors for pulse power applications. IEEE Trans. Magn. 2007, 43, 223-225. [CrossRef]

9. Azizi, A.; Gadinski, M.R.; Li, Q.; AlSaud, M.A.; Wang, J.; Wang, Y.; Wang, B.; Liu, F.; Chen, L.-Q.; Alem, N.; et al. High-performance polymers sandwiched with chemical vapor deposited hexagonal boron nitrides as scalable high-temperature dielectric materials. Adv. Mater. 2017, 29, 1701864. [CrossRef] [PubMed]

10. Chung, J.Y.; Lee, J.G.; Baek, Y.K.; Shin, P.W.; Kim, Y.K. Magnetic field-induced enhancement of thermal conductivities in polymer composites by linear clustering of spherical particles. Compos. Part B 2018, 136, 215-221. [CrossRef]

11. Liu, F.; Li, Q.; Cui, J.; Li, Z.; Yang, G.; Liu, Y.; Dong, L.; Xiong, C.; Wang, H.; Wang, Q. High-energy-density dielectric polymer nanocomposites with trilayered architecture. Adv. Funct. Mater. 2017, 27, 1606292. [CrossRef]

12. Kim, P.; Jones, S.C.; Hotchkiss, P.J.; Haddock, J.N.; Kippelen, B.; Marder, S.R.; Perry, J.W. Phosphonic acid-modified barium titanate polymer nanocomposites with high permittivity and dielectric strength. Adv. Mater. 2007, 19, 1001-1005. [CrossRef]

13. Tan, D.; Zhang, L.L.; Chen, Q.; Irwin, P. High-temperature capacitor polymer films. J. Electron. Mater. 2014, 43, 4569-4575. [CrossRef]

14. Ouyang, Y.; Hou, G.; Bai, L.; Li, B.; Yuan, F. Constructing continuous networks by branched alumina for enhanced thermal conductivity of polymer composites. Compos. Sci. Technol. 2018, 165, 307-313. [CrossRef]

15. Zhao, Y.; Zhai, Z.; Drummer, D. Thermal conductivity of aluminosilicate- and aluminum oxide-filled thermosets for injection molding: Effect of filler content, filler size and filler geometry. Polymers 2018, 10, 457. [CrossRef]

16. Liu, F.H.; Li, Q.; Li, Z.Y.; Liu, Y.; Dong, L.J.; Xiong, C.X.; Wang, Q. Poly(methyl methacrylate)/boron nitride nanocomposites with enhanced energy density as high temperature dielectrics. Compos. Sci. Technol. 2017, 142, 139-144. [CrossRef] 
17. Terao, T.; Zhi, C.Y.; Bando, Y.; Mitome, M.; Tang, C.C.; Golberg, D. Alignment of boron nitride nanotubes in polymeric composite films for thermal conductivity improvement. J. Phys. Chem. C 2010, 114, 4340-4344. [CrossRef]

18. Hu, J.T.; Huang, Y.; Yao, Y.M.; Pan, G.R.; Sun, J.J.; Zeng, X.L.; Sun, R.; Xu, J.B.; Song, B.; Wong, C.P. Polymer composite with improved thermal conductivity by constructing a hierarchically ordered three-dimensional interconnected network of BN. ACS Appl. Mater. Interfaces 2017, 9, 13544-13553. [CrossRef] [PubMed]

19. Yang, M.; Zhao, H.; He, D.; Hu, C.; Chen, H.; Bai, J. Carbon coated boron nitride nanosheets for polymer nanocomposites with enhanced dielectric performance. Materials 2017, 10, 741. [CrossRef] [PubMed]

20. Cai, Z.M.; Wang, X.H.; Luo, B.C.; Li, L.T. Hierarchical-structured dielectric permittivity and breakdown performances of polymer-ceramic nanocomposites. Ceram. Int. 2018, 44, 843-848. [CrossRef]

21. Ruan, M.N.; Yang, D.; Guo, W.L.; Zhang, L.Q.; Li, S.X.; Shang, Y.W.; Wu, Y.B.; Zhang, M.; Wang, H. Improved dielectric properties, mechanical properties, and thermal conductivity properties of polymer composites via controlling interfacial compatibility with bio-inspired method. Appl. Surf. Sci. 2018, 439, 186-195. [CrossRef]

22. Yang, C.T.; Hsiang, H.I.; Huang, T.S.; Huang, P.C.; Han, Y.K. Thermal conductivity and dielectric properties of PEDOT: PSS-AIN filler reinforced water-soluble polymer composites. Ceram. Int. 2017, 43, 710-716. [CrossRef]

23. Rajeshwari, P.; Dey, T.K. Finite element modelling and experimental investigation on effective thermal conductivity of AIN (nano) particles reinforced HDPE polymer nanocomposites. Thermochim. Acta 2016, 638, 103-112. [CrossRef]

24. Ali, A.F.; Hassan, M.L.; Ward, A.A.; El-Giar, E.M. Processing, dynamic mechanical thermal analysis, and dielectric properties of barium titanate/cellulosic polymer nanocomposites. Polym. Compos. 2017, 38, 893-907. [CrossRef]

25. Li, R.; Zhou, J.; Liu, H.; Pei, J. Effect of polymer matrix on the structure and electric properties of piezoelectric lead zirconatetitanate/polymer composites. Materials 2017, 10, 945. [CrossRef] [PubMed]

26. Yao, Y.; Zeng, X.; Guo, K.; Sun, R.; Xu, J.-b. The effect of interfacial state on the thermal conductivity of functionalized $\mathrm{Al}_{2} \mathrm{O}_{3}$ filled glass fibers reinforced polymer composites. Compos. Part A Appl. Sci. Manuf. 2015, 69, 49-55. [CrossRef]

27. Liang, S.; Chong, S.R.; Giannelis, E.P. Barium titanate/epoxy composite dielectric materials for integrated thin film capacitors. In Proceedings of the 48th Electronic Components and Technology Conference (Cat. No.98CH36206), Seattle, WA, USA, 25-28 May 1998; pp. 171-175.

28. Leung, S.N. Thermally conductive polymer composites and nanocomposites: Processing-structure-property relationships. Compos. Part B 2018, 150, 78-92. [CrossRef]

29. Chen, H.Y.; Ginzburg, V.V.; Yang, J.; Yang, Y.F.; Liu, W.; Huang, Y.; Du, L.B.; Chen, B. Thermal conductivity of polymer-based composites: Fundamentals and applications. Prog. Polym. Sci. 2016, 59, 41-85. [CrossRef]

30. Huang, C.; Qian, X.; Yang, R. Thermal conductivity of polymers and polymer nanocomposites. Mater. Sci. Eng. $R$ 2018, 132, 1-22. [CrossRef]

31. Ye, X.; Jin, L.; Caglayan, H.; Chen, J.; Xing, G.; Zheng, C.; Doan-Nguyen, V.; Kang, Y.; Engheta, N.; Kagan, C.R. Improved size-tunable synthesis of monodisperse gold nanorods through the use of aromatic additives. ACS Nano 2012, 6, 2804-2817. [CrossRef] [PubMed]

32. Zhang, D.L.; Zha, J.W.; Li, W.K.; Li, C.Q.; Wang, S.J.; Wen, Y.Q.; Dang, Z.M. Enhanced thermal conductivity and mechanical property through boron nitride hot string in polyvinylidene fluoride fibers by electrospinning. Compos. Sci. Technol. 2018, 156, 1-7. [CrossRef]

33. Yu, J.; Choi, H.K.; Kim, H.S.; Kim, S.Y. Synergistic effect of hybrid graphene nanoplatelet and multi-walled carbon nanotube fillers on the thermal conductivity of polymer composites and theoretical modeling of the synergistic effect. Compos. Part A 2016, 88, 79-85. [CrossRef]

34. Bian, Y.; Wu, C.; Li, H.; Zhai, J. A tunable metamaterial dependent on electric field at terahertz with barium strontium titanate thin film. Appl. Phys. Lett. 2014, 104, 563-597. [CrossRef]

35. Noel, K.M.; Pearson, A.M.; Curry, R.D.; O'Connor, K.A. High frequency properties of high voltage barium titanate-ferrite multiferroic metamaterial composites. IEEE Trans. Dielectr. Electr. Insul. 2016, 23, 2965-2969. [CrossRef]

36. Lee, Y.; Kim, S.J.; Park, H.; Lee, B. Metamaterials and metasurfaces for sensor applications. Sensors 2017, 17, 1726. [CrossRef] [PubMed] 
37. Perez-Medina, J.C.; Waldo-Mendoza, M.A.; Cruz-Delgado, V.J.; Quinones-Jurado, Z.V.; Gonzalez-Morones, P.; Ziolo, R.F.; Martinez-Colunga, J.G.; Soriano-Corral, F.; Avila-Orta, C.A. Metamaterial behavior of polymer nanocomposites based on polypropylene/multi-walled carbon nanotubes fabricated by means of ultrasound-assisted extrusion. Materials 2016, 9, 923. [CrossRef] [PubMed]

38. Liberal, I.; Engheta, N. Near-zero refractive index photonics. Nat. Photonics 2017, 11, 149-158. [CrossRef]

39. Bao, D.; Rajab, K.Z.; Hao, Y.; Kallos, E.; Tang, W.; Argyropoulos, C.; Piao, Y.; Yang, S. All-dielectric invisibility cloaks made of $\mathrm{BaTiO}_{3}$-loaded polyurethane foam. New J. Phys. 2011, 13, 103023. [CrossRef]

40. Mulle, M.; Wafai, H.; Yudhanto, A.; Lubineau, G.; Yaldiz, R.; Schijve, W.; Verghese, N. Process monitoring of glass reinforced polypropylene laminates using fiber bragg gratings. Compos. Sci. Technol. 2016, 123, 143-150. [CrossRef]

41. Zemouli, S.; Chaabi, A.; Talbi, H.S. Design of a compact and high sensitivity temperature sensor using metamaterial. Int. J. Antennas Propag. 2015, 2015, 1-7. [CrossRef]

42. Iovine, R.; Spada, L.L.; Vegni, L. Nanoparticle device for biomedical and optoelectronics applications. Compel 2013, 32, 1596-1608. [CrossRef]

43. Spada, L.L.; Iovine, R. Electromagnetic modeling of ellipsoidal nanoparticles for sensing applications. Opt. Eng. 2013, 52, 051205. [CrossRef]

44. Homberger, M.; Simon, U. On the application potential of gold nanoparticles in nanoelectronics and biomedicine. Philos. Trans. R. Soc. A 2010, 368, 1405-1453. [CrossRef] [PubMed]

45. Spada, L.L.; Iovine, R.; Tarparelli, R.; Vegni, L. Conical nanoparticles for blood disease detection. Adv. Nanopart. 2013, 2, 259-265. [CrossRef]

46. Liu, Y.; Hao, Y.; Li, K.; Gong, S. Radar cross section reduction of a microstrip antenna based on polarization conversion metamaterial. IEEE Antennas Wirel. Propag. Lett. 2016, 15, 80-83. [CrossRef]

47. Walker, E.L.; Wang, Z.; Neogi, A. Radio-frequency actuated polymer-based phononic meta-materials for control of ultrasonic waves. NPG Asia Mater. 2017, 9, 350. [CrossRef]

48. Spada, L.L.; Haq, S.; Hao, Y. Modeling and design for electromagnetic surface wave devices. Radio Sci. 2017, 52, 1049-1057. [CrossRef]

49. Cai, W.; Chettiar, U.K.; Kildishev, A.V.; Shalaev, V.M. Optical cloaking with metamaterials. Nat. Photonics 2007, 1, 224-227. [CrossRef]

50. Qin, F.; Ding, L.; Zhang, L.; Monticone, F.; Chan, C.C.; Deng, J.; Mei, S.; Li, Y.; Teng, J.; Hong, M. Hybrid bilayer plasmonic metasurface efficiently manipulates visible light. Sci. Adv. 2016, 2, 1501168. [CrossRef] [PubMed]

51. Popielarz, R.; Chiang, C.K.; Nozaki, R.; Obrzut, J. Dielectric properties of polymer/ferroelectric ceramic composites from $100 \mathrm{~Hz}$ to $10 \mathrm{GHz}$. Macromolecules 2001, 34, 5910-5915. [CrossRef]

52. Jayasundere, N.; Smith, B.V. Dielectric constant for binary piezoelectric 0-3 composites. J. Appl. Phys. 1993, 73, 2462-2466. [CrossRef]

53. Chiang, C.K.; Popielarz, R. Polymer composites with high dielectric constant. Ferroelectrics 2002, 275, 1-9. [CrossRef]

54. Feng, Y.Z.; He, C.G.; Wen, Y.F.; Zhou, X.P.; Xie, X.L.; Ye, Y.S.; Mai, Y.W. Multi-functional interface tailoring for enhancing thermal conductivity, flame retardancy and dynamic mechanical property of epoxy $/ \mathrm{Al}_{2} \mathrm{O}_{3}$ composites. Compos. Sci. Technol. 2018, 160, 42-49. [CrossRef]

55. Cai, Z.M.; Wang, X.H.; Luo, B.C.; Hong, W.; Wu, L.W.; Li, L.T. Dielectric response and breakdown behavior of polymer-ceramic nanocomposites: The effect of nanoparticle distribution. Compos. Sci. Technol. 2017, 145, 105-113. [CrossRef]

56. Neese, B.; Chu, B.J.; Lu, S.G.; Wang, Y.; Furman, E.; Zhang, Q.M. Large electrocaloric effect in ferroelectric polymers near room temperature. Science 2008, 321, 821-823. [CrossRef] [PubMed]

57. Li, Q.; Zhang, G.Z.; Liu, F.H.; Han, K.; Gadinski, M.R.; Xiong, C.X.; Wang, Q. Solution-processed ferroelectric terpolymer nanocomposites with high breakdown strength and energy density utilizing boron nitride nanosheets. Energy Environ. Sci. 2015, 8, 922-931. [CrossRef]

(C) 2018 by the authors. Licensee MDPI, Basel, Switzerland. This article is an open access article distributed under the terms and conditions of the Creative Commons Attribution (CC BY) license (http:/ / creativecommons.org/licenses/by/4.0/). 